\title{
Physical-chemical characterization, microbiological and biocompounds of cashew pulp in industrial and freezing processing
}

\author{
Paulo Rafael Bobbo CARRENHO ${ }^{1}$, Ana Carolina da SILVA¹, Josemar Rodrigo UEBEL ${ }^{2}$, \\ Juliana da Silva AGOSTINI ${ }^{1 \star}$ (D)
}

\begin{abstract}
This study aimed to evaluate the nutritional characteristics, bioactive compounds and microbiological quality during the processing and frozen storage of cashew pulps. Cashew pulps from 4 batches and 3 different sequential stages of industrial processing and storage (after pulping, after pulp thawing that was stored for 3 months in a drum, and 90 days after packaging in bugs and frozen storage at $-20^{\circ} \mathrm{C}$ ) were obtained and submitted to the following analyses: $\mathrm{pH}$, total soluble solids (TSS), color $\left(\mathrm{L}^{*}, \mathrm{c}^{*}\right.$ and $\left.\mathrm{H}^{\circ}\right)$, acidity, ascorbic acid, glucose reducing sugars, total phenols, antioxidant potential by reducing DPPH (1,1-diphenyl-2-picrylhydrazyl) and microbiological parameters (Fungi, psychrotrophic bacteria and coliforms). There was interaction between batches and processing steps for all evaluated parameters, except phenols in acetone extract. The acidity of all batches verified was below of the minimum value recommended by current legislation. Sugars, acidity, ascorbic acid and color were negatively affected during processing. The phenolic compounds presented slight modifications, with a slight increase between the first two stages. Although the antioxidant potential presented variations, there was no single response profile for all batches. High microbial counts were observed after pulping, however there were considerable reductions throughout the processing/storage.
\end{abstract}

Keywords: Anacardium occidentale L.; storage; conservation; bioactive compounds.

Practical Application: Verify intensity losses in quality characteristics of cashew pulp during processing storage.

\section{Introduction}

Fruits are highly appreciated for their sensory characteristics and potential health benefits due to the presence of essential nutrients for metabolism and bioactive compounds with antioxidant capacity. Antioxidants act by retarding or preventing oxidative processes, preventing the formation of free radicals (Broinizi et al., 2007; Pereira, 2013). Fruits and other vegetables contain numerous antioxidant substances, such as phenolic compounds, which are substances with great variety of structures, presence of an aromatic ring with one or more hydroxyl substituents, including their functional groups (Angelo \& Jorge, 2007). Examples include flavonoids, phenolic acids, simple phenols, coumarins, tannins, lignins and tocopherols (Shahidi \& Naczk, 1995; Angelo \& Jorge, 2007).

Cashew (Anacardium occidentale L.) is a typical fruit from Northeast Brazil and its cultivation is increasingly acquiring socioeconomic importance. Its peduncle can be consumed in natura or used in the production of pulps, juices, nectars and sweets. It presents excellent sensory properties and high ascorbic acid content (Lima et al., 2004; Figueiredo et al., 2007). The stalk is highly fragile and perishable (Alzamora et al., 1992), making it susceptible to intense mechanisms of microbiological degradation (Figueiredo et al., 2007), which contribute to a yield of less than $6 \%$ of the national production. Therefore it is important to develop technological processes to increase its shelf life and maintain its nutritional and functional quality.

The fruit pulp is the product obtained from the edible part of the fruits, after grinding and/or pulping and preserved by physical processes such as pasteurization and freezing (Brunini et al., 2003). Consumers are looking for a new standard of convenience in food, and the quality and nutritional value should be preserved (Agostini-Costa et al., 2003; Burdurlu et al., 2006). Some studies indicated that losses and changes of bioactive compounds, vitamins and provitamins occur in the fruit processing during and aftter and overall on storage conditions (Mororó, 2000; Agostini-Costa et al., 2003; Chitarra \& Chitarra, 2005; Fernandes et al., 2007).

Freezing is one of the most efficient methods for storage food for long periods since it reduces the effects of spoilage and makes it possible to maintain fruits quality and their products. It allows the use of fruits as raw material in the industrialization of other food products and, although efficient in maintaining the organoleptic characteristics of fruits (Brunini et al., 2003), it depends on the speed, the cooling medium and the subsequent storage conditions (Fennema et al., 1973; Fernandes et al., 2010). The freezing is for the purpose of preserving food stored for long periods. However, changes can occur even at temperatures below $0{ }^{\circ} \mathrm{C}$. Frozen speed and temperature stability during 
storage is able to maintaining quality (Agostini-Costa et al., 2003; Silva et al., 2010b).

The data about tropical pulp fruit stability during processing and frozen storage are scarce. Therefore, this study aimed to investigate physical chemical, bioactive compounds and microbiological quality of cashew pulp during industrial processing and storage conditions.

\section{Materials and methods}

Samples of cashew pulps (Anacardium occidentale L.) from 4 batches and different sequential steps of industrial processing and storage (1 - immediately after pulping; 2 - immediately after thawing the pulped stock for 90 days in a drum containing $160 \mathrm{~kg}$ of bulk pulp; 3 - three months after packaging in sachets and frozen storage at $-20^{\circ} \mathrm{C}$ ) were obtained from a fruit pulp industry located in the northern region of Mato Grosso state (Brazil). Pulp samples were aseptically packaged and carried out to the Food Technology Laboratory of the Universidade Federal de Mato Grosso, campus Sinop. Then, the $\mathrm{pH}$ was measured by direct reading on a digital $\mathrm{pH}$ meter $\left(\mathrm{Tecnal}^{\circledR}{ }^{\circledR}, \mathrm{Tec}-5\right)$; acidity expressed in citric acid by titration; the total soluble solids (TSS $/{ }^{\circ}$ Brix) were determined by refractometry method, using an Abbé refractometer with a graduated scale in brix; the glucose-reducing sugars were determined by the Lane-Eynon titration method (Instituto Adolfo Lutz, 2008). The ascorbic acid content (vitamin C) was determined by titration with DCFI (2.6 dichlorophenol indophenol) (Association of Official Analytical Chemists, 1997).

A colorimeter (Kônica Minolta ${ }^{\circledR}$-c400) was used to determine the instrumental color, on the illuminant D65, and direct reflectance reading of the coordinates $\mathrm{L}^{*}, \mathrm{a}^{*}$ and $\mathrm{b}^{*}$. The pitch angle hue $\left({ }^{\circ} h^{\star}\right)$ and Chroma saturation $\left(c^{\star}\right)$ were calculated from the parameters $\mathrm{a}^{*}$ and $\mathrm{b}^{*}$ by the formulas ${ }^{\circ} \mathrm{h}^{*}=\arctan \left(\mathrm{b}^{*} / \mathrm{a}^{*}\right)$ and $\mathrm{c}^{*}=\sqrt{a^{* 2}+b^{* 2}}$.

The most probable number $\left(\mathrm{MPN} \mathrm{g}^{-1}\right)$ of coliforms at $35^{\circ} \mathrm{C}$ and thermotolerant coliforms at $45^{\circ} \mathrm{C}$, total counts $\left(\mathrm{CFU} \mathrm{g}{ }^{-1}\right)$ of molds and yeasts as well as the total psychrophilic aerobic microorganisms were determined by the method of standard plaque counts (Silva et al., 2010a).

Total phenolic compounds were determined according to the method of Folin-Ciocalteau (Singleton \& Rossi, 1965), based on the cold extractions and reactions proposed by Rocha et al. (2011) using three different solvents: $70 \%$ acetone, 95\% ethanol and methanol. The absorbances were obtained in a spectrophotometer (BioSpectro) at $760 \mathrm{~nm}$. The results were expressed as mg of equivalent gallic acid (AGE) $100 \mathrm{~g}^{-1}$. Galic acid was used as standard.

The antioxidant potential of the pulp was evaluated by the 1,1-diphenyl-2-picrylhydrazyl (DPPH) assay, according to Brand-Williams et al. (1995), with extraction and reaction standardized by Rufino et al. (2007). The reduction of the DPPH radical was measured in a spectrophotometer (Biospectro) at $515 \mathrm{~nm}$ just after 30 minutes of rest. Sequestration of free radicals with decrease in the absorbance values of the samples was correlated with the control and the percentage of discoloration of the DPPH radical was established. The results were expressed as IC 50 (Lim et al., 2007; Rufino et al., 2007).

Data assay were analysed by the Assistat Software Version 7.7 (Silva \& Azevedo, 2016) in a completely randomized design with a factorial arrangement $3 \times 4$ with three process steps, four blocks (batches). The data were submitted to analysis of variance, and the means of the treatments were compared by Tukey test $(\mathrm{p}<0.05)$.

\section{Results and discussion}

Table 1 is presented the results of physical-chemical parameters analyzed in cashew pulps of 4 batches and 3 distinct stages of industrial processing. In all the parameters there were significant interaction between them.

In general, $\mathrm{pH}$ values increased, especially between the second and third stages, coinciding specifically with the period of frozen pulp storage in sachets. All the values obtained are suitable according to current legislation (Brasil, 2000). Silva et al. (2013) characterized the frozen pulp cashew and observed a pH of 3.99. Castro et al. (2015) emphasize that pH lower than 4.5 results in pulps with greater resistance to microbial contaminations, with quality preservation and no using high thermal treatment. This low $\mathrm{pH}$ aid to reduce cost to industrialization (Aroucha et al., 2010).

All acidity expressed in citric acid values, regard of lot and stage, were below of minimum established $(0.30 \mathrm{~g}$ of citric acid $\left.100 \mathrm{~g}^{-1}\right)$. There was a trend in reducing the acidity as the industrial steps followed ahead, especially in the third stage, in three batches assessed. This probably happened by organic acids presents. Organic acids are intermediate products of respiratory metabolism of fruits and are relevant to confer flavor, flavor, odor, stability and maintenance of product quality (Oliveira et al., 1999; Castro et al., 2015). It is considered an important parameter in the determination of the state of conservation of a food product, because in the decomposition process, either by hydrolysis, oxidation or fermentation. This lead to changes in the concentration of the hydrogen ions, and consequently their acidity (Aroucha et al., 2010). Their contents, in general, tend to decrease due to the respiratory process or its conversion into sugars in fruits (Becker, 2015).

For TSS, except for batch 3 in the first step, the remaining samples were below the minimum acceptable content $\left(10^{\circ} \mathrm{Brix}\right)$. Soluble solids are used as indicators of the total sugars in fruits and the maturity index of some fruits. They represent the water-soluble compounds, such as sugars, acids, phenolics, vitamins, and pectins. Glucose-reducing sugars increased in all batches throughout the process or industrial steps. Nogueira et al. (2007) justify that the increase of reducing sugars occurs possibly due to hydrolysis of the starch and inversion of sucrose in glucose and fructose. It is an important parameter in the production of fruits destined to the processing of juices and pulps, as it results in a better yield and sweet taste (Brasil et al., 2016).

The literature presents $\mathrm{pH}$, acidity (citric acid), TSS and reducing sugars values in cashew pulps ranging from

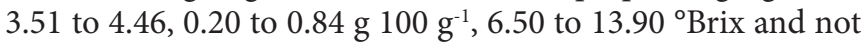


Table 1. Physical-chemical parameters of cashew pulps of 4 batches in 3 stages of processing.

\begin{tabular}{|c|c|c|c|c|}
\hline \multirow{2}{*}{ Parameters } & \multirow{2}{*}{ batch } & \multicolumn{3}{|c|}{ Processing step } \\
\hline & & 1 & 2 & 3 \\
\hline \multirow[t]{4}{*}{$\mathrm{pH}$} & 1 & $3.84 \pm 0.03 \mathrm{cB}$ & $3.98 \pm 0.06 \mathrm{bA}$ & $4.07 \pm 0.03 \mathrm{aB}$ \\
\hline & 2 & $4.22 \pm 0.03 \mathrm{bA}$ & $4.21 \pm 0.02 \mathrm{bA}$ & $4.40 \pm 0.01 \mathrm{aA}$ \\
\hline & 3 & $4.21 \pm 0.03 \mathrm{bA}$ & $4.30 \pm 0.10 \mathrm{abA}$ & $4.41 \pm 0.01 \mathrm{aA}$ \\
\hline & 4 & $4.16 \pm 0.11 \mathrm{aA}$ & $4.07 \pm 0.20 \mathrm{aA}$ & $4.26 \pm 0.11 \mathrm{aA}$ \\
\hline \multirow{4}{*}{$\begin{array}{l}\text { Acidity in citric acid } \\
\qquad\left(\mathrm{g} 100 \mathrm{~g}^{-1}\right)\end{array}$} & 1 & $0.24 \pm 0.01 \mathrm{aB}$ & $0.24 \pm 0.02 \mathrm{aBC}$ & $0.19 \pm 0.01 \mathrm{bA}$ \\
\hline & 2 & $0.19 \pm 0.01 \mathrm{bC}$ & $0.25 \pm 0.00 \mathrm{aB}$ & $0.19 \pm 0.00 \mathrm{bA}$ \\
\hline & 3 & $0.19 \pm 0.01 \mathrm{aC}$ & $0.22 \pm 0.02 \mathrm{aC}$ & $0.21 \pm 0.00 \mathrm{aA}$ \\
\hline & 4 & $0.27 \pm 0.02 \mathrm{aA}$ & $0.28 \pm 0.01 \mathrm{aA}$ & $0.21 \pm 0.01 \mathrm{bA}$ \\
\hline \multirow[t]{4}{*}{ TSS ( ${ }^{\circ}$ Brix $)$} & 1 & $9.20 \pm 0.00 \mathrm{bC}$ & $9.50 \pm 0.00 \mathrm{aA}$ & $9.25 \pm 0.00 \mathrm{bB}$ \\
\hline & 2 & $9.10 \pm 0.00 \mathrm{cC}$ & $9.25 \pm 0.00 \mathrm{bB}$ & $9.50 \pm 0.00 \mathrm{aA}$ \\
\hline & 3 & $10.10 \pm 0.10 \mathrm{aA}$ & $9.50 \pm 0.00 \mathrm{bA}$ & $9.25 \pm 0.00 \mathrm{cB}$ \\
\hline & 4 & $9.92 \pm 0.14 \mathrm{aB}$ & $9.50 \pm 0.00 \mathrm{bA}$ & $9.25 \pm 0.00 \mathrm{cB}$ \\
\hline \multirow{4}{*}{$\begin{array}{l}\text { Glucose-reducing sugars } \\
\qquad\left(\mathrm{g} 100 \mathrm{~g}^{-1}\right)\end{array}$} & 1 & $3.6 \pm 0.04 \mathrm{cC}$ & $5.52 \pm 0.17 \mathrm{bA}$ & $6.71 \pm 0.05 \mathrm{aAB}$ \\
\hline & 2 & $5.58 \pm 0.01 \mathrm{aA}$ & $5.43 \pm 0.12 \mathrm{aA}$ & $6.06 \pm 0.15 \mathrm{aB}$ \\
\hline & 3 & $3.80 \pm 0.06 \mathrm{bBC}$ & $3.91 \pm 0.32 \mathrm{bB}$ & $6.43 \pm 0.24 \mathrm{aAB}$ \\
\hline & 4 & $4.42 \pm 0.62 \mathrm{cB}$ & $5.50 \pm 0.67 \mathrm{bA}$ & $6.79 \pm 0.31 \mathrm{aA}$ \\
\hline \multirow[t]{4}{*}{ Color $\left(L^{*}\right)$} & 1 & $72.55 \pm 0.08 \mathrm{aA}$ & $64.44 \pm 0.85 \mathrm{bB}$ & $63.77 \pm 0.45 \mathrm{bA}$ \\
\hline & 2 & $67.91 \pm 0.20 \mathrm{aB}$ & $65.55 \pm 0.36 \mathrm{bAB}$ & $63.59 \pm 0.52 \mathrm{cA}$ \\
\hline & 3 & $66.55 \pm 0.93 \mathrm{aC}$ & $66.16 \pm 0.84 \mathrm{aA}$ & $63.99 \pm 0.31 \mathrm{bA}$ \\
\hline & 4 & $66.64 \pm 0.62 \mathrm{aC}$ & $65.69 \pm 0.36 \mathrm{aA}$ & $64.01 \pm 0.19 \mathrm{bA}$ \\
\hline \multirow[t]{4}{*}{ Color $\left({ }^{*} \mathrm{c}\right)$} & 1 & $27.19 \pm 0.19 \mathrm{aC}$ & $24.02 \pm 0.68 \mathrm{bC}$ & $22.22 \pm 0.24 \mathrm{cC}$ \\
\hline & 2 & $30.19 \pm 0.52 \mathrm{aA}$ & $26.76 \pm 0.47 \mathrm{bB}$ & $24.23 \pm 0.89 \mathrm{cB}$ \\
\hline & 3 & $28.21 \pm 0.51 \mathrm{aBC}$ & $28.15 \pm 0.39 \mathrm{aA}$ & $26.91 \pm 0.62 \mathrm{bA}$ \\
\hline & 4 & $28.49 \pm 0.62 \mathrm{aB}$ & $28.16 \pm 0.43 \mathrm{aA}$ & $25.95 \pm 0.31 \mathrm{bA}$ \\
\hline \multirow[t]{4}{*}{ Color $\left({ }^{\circ} h^{*}\right)$} & 1 & $86.77 \pm 0.30 \mathrm{aA}$ & $79.77 \pm 0.67 \mathrm{bB}$ & $80.31 \pm 0.77 \mathrm{bC}$ \\
\hline & 2 & $86.56 \pm 0.55 \mathrm{aA}$ & $81.36 \pm 0.44 \mathrm{bA}$ & $81.22 \pm 1.15 \mathrm{bBC}$ \\
\hline & 3 & $81.35 \pm 0.28 \mathrm{aB}$ & $81.18 \pm 0.49 \mathrm{aAB}$ & $81.98 \pm 0.78 \mathrm{aAB}$ \\
\hline & 4 & $81.56 \pm 0.12 \mathrm{bB}$ & $81.73 \pm 0.35 \mathrm{bA}$ & $83.09 \pm 1.15 \mathrm{aA}$ \\
\hline
\end{tabular}

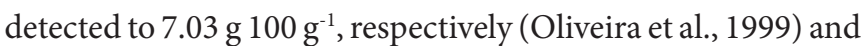
3.34 to $4.34,0.21$ to $0.81 \mathrm{~g}$. $100 \mathrm{~g}^{-1}, 9.47$ to $13.75,3.19$ to $6.95{\mathrm{~g} 100 \mathrm{~g}^{-1}}^{-1}$ (citric acid), respectively (Brasil et al., 2016). Important variations in the parameters of $\mathrm{pH}$, acidity and TSS, which interfere with the quality of frozen fruit pulps, have been detected, either between different brands or batches of products or during stages of industrialization and frozen storage (Brunini et al., 2003; Raimundo et al., 2009; Sebastiany et al., 2009; Damiani et al., 2013). The variations observed can be justified according to the origin of the fruit (soil, season, production system, maturation) and handling (transport, packaging, processing and storage) and besides indicating deficiencies in the standardization and quality control of the materials used in the pulp industry. It is noteworthy that eventual addition of water during processing reduces soluble solids (Brasil et al., 2016; Castro et al., 2015).

In the color coordinate $\mathrm{L}^{*}$, there were small variations between the batches and significant reduction of the values along the stages, indicating a small blackening of the pulp. In the case of the parameter $\mathrm{c}^{\star}$, a reduction of the values was also observed as the steps forward, indicating loss of intensity or saturation of the color. As for tonality $\left({ }^{\circ} h^{\star}\right)$, there were differentiated behaviors among the lots, but the first two lots reduced the yellow hue between the first two stages. The yellow tone is influenced by the carotenoids present in the cashew, mainly $\beta$-carotene (Silva et al., 2013; Castro et al., 2015).

Variations in the values of instrumental color parameters may represent differences, especially in the harvesting season and in the maturation stage of the raw material (Castro et al., 2015). Color changes may indicate unstable pigment loss during processing. Natural pigments are affected during the food processing stages by the action of light, temperature, oxygen, metal ions and enzymes (Stintzing et al., 2002) until presence or microorganisms.

The ascorbic acid content (Table 2) ranged from 182.84 to $336.69 \mathrm{mg} 100 \mathrm{~g}^{-1}$, being higher han those reported by Sancho et al. (2007) and Silva et al. (2012) and partially similar the freshly processed pulps evaluated by Figueiredo et al. (2007). There was variation in the ascorbic acid contents of cashew pulps, with reduction in three of the four batches evaluated, mainly from the second to the third processing stage. Even with such reductions, all samples presented values of ascorbic acid above the minimum required (Brasil, 2000). The first batch was the only one that did not present significant variation, coinciding 
Carrenho et al.

Table 2. Bioactive compounds of cashew pulps of 4 batches in 3 stages of industrial processing.

\begin{tabular}{|c|c|c|c|c|}
\hline \multirow{2}{*}{ Parameter } & \multirow{2}{*}{ batch } & \multicolumn{3}{|c|}{ Processing step } \\
\hline & & 1 & 2 & 3 \\
\hline \multirow{3}{*}{ 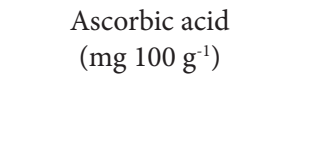 } & 1 & $233.07 \pm 8.72 \mathrm{aC}$ & $248.50 \pm 24.98 \mathrm{aB}$ & $260.63 \pm 23.63 \mathrm{aA}$ \\
\hline & 2 & $336.69 \pm 1.98 \mathrm{aA}$ & $247.19 \pm 17.49 \mathrm{bB}$ & $259.51 \pm 9.95 \mathrm{bA}$ \\
\hline & 4 & $273.83 \pm 4.09 \mathrm{aB}$ & $296.97 \pm 10.94 \mathrm{aA}$ & $182.84 \pm 17.11 \mathrm{bB}$ \\
\hline \multirow{2}{*}{$\begin{array}{l}\text { Total phenols (AE) } \\
\quad\left(\mathrm{mg} 100 \mathrm{~g}^{-1}\right)\end{array}$} & 1 & $42.36 \pm 0.30$ & $43.84 \pm 0.67$ & $46.52 \pm 0.58$ \\
\hline & 4 & $46.41 \pm 0.20$ & $46.75 \pm 0.35$ & $44.48 \pm 1.15$ \\
\hline \multirow{4}{*}{$\begin{array}{l}\text { Total phenols (EE) } \\
\qquad\left(\mathrm{mg} 100 \mathrm{~g}^{-1}\right)\end{array}$} & 1 & $135.00 \pm 1.69 \mathrm{bA}$ & $188.03 \pm 10.90 \mathrm{aA}$ & $145.21 \pm 4.28 \mathrm{bA}$ \\
\hline & 2 & $132.64 \pm 1.56 \mathrm{bA}$ & $207.90 \pm 33.37 \mathrm{aA}$ & $137.83 \pm 5.17 \mathrm{bA}$ \\
\hline & 3 & $132.73 \pm 1.82 \mathrm{aA}$ & $134.87 \pm 2.69 \mathrm{aB}$ & $97.32 \pm 4.49 \mathrm{bB}$ \\
\hline & 4 & $139.14 \pm 2.13$ & $139.71 \pm 6.31 \mathrm{aB}$ & $124.47 \pm 0.91 \mathrm{aA}$ \\
\hline \multirow[t]{4}{*}{ DPPH (IC 50) (mg mL $\left.{ }^{-1}\right)$} & 1 & $1.25 \pm 0.08 \mathrm{aA}$ & $0.95 \pm 0.03 \mathrm{bAB}$ & $0.84 \pm 0.13 \mathrm{bB}$ \\
\hline & 2 & $0.71 \pm 0.02 \mathrm{bC}$ & $0.95 \pm 0.03 \mathrm{aAB}$ & $0.93 \pm 0.01 \mathrm{aAB}$ \\
\hline & 3 & $0.99 \pm 0.04 \mathrm{aB}$ & $0.93 \pm 0.02 \mathrm{aB}$ & $0.92 \pm 0.01 \mathrm{aAB}$ \\
\hline & 4 & $0.71 \pm 0.05 \mathrm{bC}$ & $1.12 \pm 0.19 \mathrm{aA}$ & $1.04 \pm 0.12 \mathrm{aA}$ \\
\hline
\end{tabular}

$\mathrm{DPPH}=1,1$-diphenyl-2-picrylhydrazyl; $\mathrm{AE}=70 \%$ acetonic extract; $\mathrm{EE}=95 \%$ ethanolic extract; $\mathrm{ME}=$ Methanolic extract. For each parameter, different lowercase letters in the same row and different capitals in the same column indicate significant differences between them $(\mathrm{p}<0.05)$.

with the one with the lowest $\mathrm{pH}$ values. Brasil et al. (2016) emphasize the effects of $\mathrm{pH}$ on the stability of ascorbic acid, where its irreversible catabolism can be increased at alkaline $\mathrm{pH}$, and acidification may aid in its stabilization. Variations between batches may be generally associated with pre and post harvest factors such as environmental influences (soil conditions, climate, rainfall), maturity stage of the fruit, processing and/or storage conditions, distribution and commercialization (Castro et al., 2015). Ascorbic acid is a very unstable antioxidant because it is easily degraded in the presence of light and temperature variations (Brasil et al., 2016). Therefore, its retention is often used as an indication of the nutritional quality and even the state of food preservation (Oliveira et al., 2012). Interactions with other substances and enzymes present in the food also contribute to its reduction (Silva et al., 2011). The decrease along the steps can be justified by its interaction with oxygen and even by the temperature variations that occur along the stages, in which the product goes through processes of freezing and thawing. Considering that in step 2 the thawed bulk product is fractionated for small sachets, there will be a greater exposure of the vitamin and interaction with the oxygen present, which according to Sancho et al. (2007), will lead to a natural decrease as a function of time.

Total phenolic compounds extracted with 95\% ethanol and methanol increased between the process and storage steps, especially from the first to the second step. There was no influence of lots and processing steps on the contents of phenol compounds extracted with $70 \%$ acetone. Haida et al. (2015) verified that during the freezing of guavas for a period of 30 days there was a significant increase in the content of phenolic compounds and a discrete decrease between 30 and 60 days of freezing. It is considered that this behavior can be justified by the action of the enzyme phenylalanine ammonia-lyase and other enzymes, which act on the secondary metabolism, forming other phenolic compounds (Freire et al., 2013; Edagi et al., 2009).

Regarding the antioxidant capacity, there was no definite trend of response between the process and storage stages, because in one of the batches of pulps there were no significant changes during the 3 stages, in two batches of cashew pulps there was a reduction of the antioxidant capacity between the first two process steps and in one batch the antioxidant activity of step 2 was greater than step 1 .

The bioactive compounds present in the fruits are susceptible to the oxidation reactions that occur during their processing and storage, since some compounds are unstable (Melo et al., 2008). In general it is considered that prolonged periods of refrigeration or very low temperatures generate a loss in the quality of the fruits. These damages are due to the action of specific enzymes, such as peroxidase and polyphenoloxidase, which participate in the oxidation of phenolic compounds and, therefore, may decrease the antioxidant capacity of frozen pulps (Freire et al., 2013). In addition, Cheftel et al. (1989) explain that at $-18{ }^{\circ} \mathrm{C}$, an appreciable portion of water remains in the liquid state, and may migrate to the atmosphere within the package or to the environment. As a consequence, there are undesirable changes in the appearance and acceleration of oxidative reactions in the product.

In general the amounts of microorganisms (Table 3 ) counted in the first two batches were higher compared to the other batches and the first stage counts were higher for the two subsequent stages. Cashew pulp contains high levels of water, sugars and 
Table 3. Microbiological parameters of cashew pulps of 4 batches in 3 stages of processing.

\begin{tabular}{|c|c|c|c|c|}
\hline \multirow{2}{*}{ Parameter } & \multirow{2}{*}{ batch } & \multicolumn{3}{|c|}{ Processing step } \\
\hline & & 1 & 2 & 3 \\
\hline \multirow{3}{*}{$\begin{array}{l}\text { Molds and yeasts } \\
\left(\text { CFU.g }{ }^{-1}\right)\end{array}$} & 1 & $2.21 \times 10^{6}$ & $7.16 \times 10^{6}$ & $1.28 \times 10^{5}$ \\
\hline & 2 & $6.38 \times 10^{6}$ & $3.62 \times 10^{6}$ & $4.65 \times 10^{4}$ \\
\hline & 4 & $4.64 \times 10^{4}$ & $1.47 \times 10^{6}$ & $6.20 \times 10^{4}$ \\
\hline \multirow{2}{*}{$\begin{array}{l}\text { Microrganismos } \\
\text { psicrotróficos }\left(\mathrm{CFU} \cdot \mathrm{g}^{-1}\right)\end{array}$} & 1 & $4.45 \times 10^{5}$ & $4.70 \times 10^{3}$ & $9.5 \times 10^{3}$ \\
\hline & 4 & $2.50 \times 10^{5}$ & $<3$ & $<3$ \\
\hline \multirow{4}{*}{$\begin{array}{l}\text { Coliforms at } 35^{\circ} \mathrm{C} \\
\left(\text { MPN.g }{ }^{-1}\right)\end{array}$} & 1 & 35 & $<3$ & $<3$ \\
\hline & 2 & 53 & $<3$ & $<3$ \\
\hline & 3 & 11 & $<3$ & $<3$ \\
\hline & 4 & 11 & $<3$ & $<3$ \\
\hline
\end{tabular}

high SST/acidity ratio (Gadelha et al., 2009), thus representing a good substrate for the development of microorganisms. Therefore, high counts of microorganisms may be a common feature in newly processed cashews (Pinheiro et al., 2006).

The coliforms were detected in the first stage, soon after the pulp, and were eliminated in later stages, when the product would possibly be available for sale. All samples showed mold and yeast counts above the acceptable limit (Brasil, 2000), even after several freezing and thawing stages. High counts represent, in addition to the deterioration problem, which results in sensorial impairment and avoidance product by the consumer, risks to public health due to the possible production of mycotoxins by some species of fungi resistant to heat, freezing, some antibiotics and irradiation, being able to to contaminate even foods subject to technological processes (Santos et al., 2008).

It should also be considered that the pulps were not submitted to any kind of thermal treatment of sanitizing, such as pasteurization, which is proven to reduce the normal microflora and controls the growth of certain pathogens. Castro et al. (2015) emphasize that pasteurization is efficient in inhibiting the growth of filamentous fungi and yeasts. Therefore, it is believed that some of these strategies could influence the microbiota control of the fruit pulps analyzed in the present study.

Later, in the following stages, it became clear that the freeze/thaw processes, which are routine in the industry where the samples were collected, led to a reduction of the microbial load, since in the last step, the counts of coliforms, fungi yeasts and psychotrophic microorganisms were much lower in relation to freshly pulped fruit.

The reduction of microbial counts, observed in subsequent processing steps, is due to the deleterious effect related to the sequential freeze-thaw processes. Furthermore, when freshly processed pulps (step 1) are packaged in bulk into large drums and brought to a slow freeze, the formation of large ice crystals can thus occur which damage the cells of the microorganisms, which results in apoptosis (Franco \& Landgraf, 2008). When freezing reaches the range of $-6{ }^{\circ} \mathrm{C}$ to $-15{ }^{\circ} \mathrm{C}$, there is the crystallization of the water present in the medium, the increase of the solute concentration in the thawed fraction and the absence of formation of intracellular ice crystals by the control of the plasma membrane. The extent of the damage caused by intracellular ice depends on the degree of ice formation and the size of the crystals, and such effects are responsible for the irreversible damages that reach the plasma membrane and that can often cause cell death (Sola et al., 2012).

\section{Conclusions}

Our results suggest that physical chemical parameters are in disagreement with current legislation or near by current legislation, suggesting that the initial sanitary conditions of the fruits received by the industry interfered in the quality of the final product. Many of the physicochemical characteristics of the pulps were affected by the different batches and stages of production and triggered negative consequences as the processing and storage steps were advanced. Regarding the microorganisms count, the storage time under freezing was favorable, since the microbial counts regressed as the industrial stages were advanced.

\section{Acknowledgements}

To Universidade Federal de Mato Grosso for providing the physical structure and Fundação de Amparo a Pesquisa de Mato Grosso (FAPEMAT) for the scholarship.

\section{References}

Agostini-Costa, T. S., Abreu, L. N., \& Rossetti, A. G. (2003). Efeito do congelamento e do tempo de estocagem da polpa de acerola sobre o teor de carotenóides. Revista Brasileira de Fruticultura, 25(1), 56-58. http://dx.doi.org/10.1590/S0100-29452003000100017.

Alzamora, S. M., Argaiz, A., \& Welti, J. (1992). Fruit preservation by combined factors. Food Research International, 25, 159-165. 
Angelo, P. M., \& Jorge, N. (2007). Compostos fenólicos em alimentos: uma breve revisão. Revista do Instituto Adolfo Lutz, 66(1), 1-9.

Aroucha, E. M. M., Gois, V. A., Leite, R. H. L., Santos, M. C. A., \& Souza, M. S. (2010). Acidez em frutas e hortaliças. Verde, 5(2), 1-4.

Association of Official Analytical Chemists - AOAC. (1997). Official methods of analysis of the AOAC (Vol. 2, pp. 16-17). Washington: AOAC.

Becker, F. S. (2015). Desenvolvimento, caracterização e atividade antioxidante de marmelada-de-cachorro (Schum.) (Tese de doutorado). Universidade Federal de Lavras, Lavras.

Brand-Williams, W., Cuvelier, M. E., \& Berset, C.. (1995). Use of free radical method evaluate antioxidant activity. LebensmittelWissenschaft + Technologie, 28(1), 25-30. http://dx.doi.org/10.1016/ S0023-6438(95)80008-5.

Brasil, A. S., Sigarini, K. S., Pardinho, F. C., Faria, R. A. P. G., \& Siqueira, N. F. M. P. (2016). Avaliação da qualidade físico-química de polpas de fruta congeladas comercializadas na cidade de Cuiabá-MT. Revista Brasileira de Fruticultura, 38(1), 167-175. http://dx.doi. org/10.1590/0100-2945-253/14.

Brasil, Ministério da Agricultura e do Abastecimento. (2000). Aprova o regulamento técnico para fixação dos padrões de identidade e qualidade para polpa de fruta (Instrução Normativa $n^{\circ} 1$, de 7 de janeiro de 2000). Diário Oficial [da] República Federativa do Brasil, seção 1, p. 54.

Broinizi, P. R. B., Andrade-wartha, E. R. S., Silva, A. N. O., Novoa, A. J. V., Torres, R. P., Azeredo, H. M. C., Alves, R. E., \& Mancini-Filho, J. (2007). Avaliação da atividade antioxidante dos compostos fenólicos naturalmente presentes em subprodutos do pseudofruto de caju (Anacardium occidentale L.). Food Science and Technology, 27(4), 902-908. http://dx.doi.org/10.1590/S0101-20612007000400035.

Brunini, M. A., Oliveira, A. L., \& Varanda, D. B. (2003). Avaliação da qualidade de polpa de goiaba 'paluma' armazenada a $-20{ }^{\circ} \mathrm{C}$. Revista Brasileira de Fruticultura, 25(3), 394-396. http://dx.doi.org/10.1590/ S0100-29452003000300008.

Burdurlu, H. S., Koca, N., \& Karadeniz, F. (2006). Degradation of vitamin $\mathrm{C}$ in citrus juice concentrates during storage. Journal of Food Engineering, 74(2), 211-216. http://dx.doi.org/10.1016/j. jfoodeng.2005.03.026.

Castro, T. M. N., Zamboni, P. V., Dovadoni, S., Cunha, A. No., \& Rodrigues, L. J. (2015). Parâmetros de qualidade de polpas de frutas congeladas. Revista do Instituto Adolfo Lutz, 74(4), 426-436.

Cheftel, J. C., Cheftel, H., \& Besançon, P. (1989). Metodos de conservacion. In J. C. Cheftel, H. Cheftel \& P. Besançon (Eds.), Introduction a la bioquimica y tecnologia de los alimentos (cap. 7, Vol. 2, pp. 173-299). Zagaroza: Acribia.

Chitarra, M. I. F., \& Chitarra, A. B. (2005). Pós-colheita de frutos e hortaliças: fisiologia e manuseio (2. ed.). Lavras: Editora UFLA.

Damiani, C., Lage, M. E., Silva, F. L., Pereira, P., Becker, F. S., \& boas, E. V. B. V. (2013). Changes in the physicochemical and microbiological properties of frozen araça pulp during storage. Food Science and Technology, 33(1), 19-27. http://dx.doi.org/10.1590/S010120612013000500004.

Edagi, F. K., Sestari, I., Sasaki, F. F., Cabral, S. M., Meneghini, J., \& Kluge, R. A. (2009). Aumento do potencial de armazenamento refrigerado de nêsperas 'Fukuhara' com o uso de tratamento térmico. Pesquisa Agropecuária Brasileira, 44(10), 1270-1276. http://dx.doi.org/10.1590/ S0100-204X2009001000009.

Fennema, O., Powrie, W. D., \& Marth, E. H. (1973). Low temperature preservations of foods and living. New York: Marcel Dekker.
Fernandes, A. G., Maia, G. A., Sousa, H. M., Costa, J. M. C., Figueiredo, R. W., \& Prado, G. M. (2007). Comparação dos teores em vitamina C, carotenóides totais, antocianinas totais e fenólicos totais do suco tropical de goiaba nas diferentes etapas de produção e influência da armazenagem. Alimentos e Nutrição, 1(4), 431-438.

Fernandes, T. N., Resende, J. V., Cruvinel, R. S. R., \& Reno, M. J. (2010). Relação entre o comportamento reológico e a dinâmica do congelamento e descongelamento de polpa de morango adicionada de sacarose e pectina. Food Science and Technology, 30(1), 188-204. http://dx.doi.org/10.1590/S0101-20612010000100029.

Figueiredo, R. W., Lajolo, F. M., Alves, R. E., Filgueiras, H. A. C., Maia, G. A., \& Sousa, P. H. M. (2007). Qualidade de pedúnculos de caju submetidos à aplicação pós-colheita de cálcio e armazenados sob refrigeração. Pesquisa Agropecuária Brasileira, 42(4), 475-482. http:// dx.doi.org/10.1590/S0100-204X2007000400004.

Franco, B. D. G. M., \& Landgraf, M. (2008). Microbiologia de alimentos. São Paulo: Atheneu.

Freire, J. M., Abreu, C. M. P., Rocha, D. A., Corrêa, A. D., \& Marques, N. R. (2013). Quantificação de compostos fenólicos e ácido ascórbico em frutos e polpas congeladas de acerola, caju, goiaba e morango. Ciência Rural, 43(12), 2291-2295. http://dx.doi.org/10.1590/S010384782013005000132 .

Gadelha, A. J. F., Rocha, C. O., Vieira, F. F., \& Ribeiro, G. N. (2009). Avaliação de parâmetros de qualidade físico-químicos de polpas congeladas de abacaxi, acerola, cajá e caju. Revista Caatinga, 22(1), 115-118.

Haida, K. S., Haas, J., De Mello, S. A., Haida, K. S., Abrão, R. M. E., \& Sahd, R. (2015). Compostos fenólicos e atividade antioxidante de goiaba (Psidium guajava L.) fresca e congelada. Revista Fitos, 9(1), 37-44.

Instituto Adolfo Lutz - IAL. (2008). Métodos físico-químicos para análise de alimentos. São Paulo: IAL.

Lim, Y. Y., Lim, T. T., \& Tee, J. J. (2007). Antioxidant properties of several tropical fruits: a comparative study. Food Chemistry, 103(3), 10031008. http://dx.doi.org/10.1016/j.foodchem.2006.08.038.

Lima, A. C., García, N. G. P., \& Lima, J. R. (2004). Obtenção e caracterização dos principais produtos do caju. B.CEPPA, 22(1), 133-144. http://dx.doi.org/10.5380/cep.v22i1.1185.

Melo, E. A., Marciel, S. I. M., Lima, G. A. L. V., \& Araújo, R. C. (2008). Teor de fenólicos totais e capacidade antioxidante de polpas congeladas de frutas. Alimentos e Nutrição, 19(1), 67-72.

Mororó, R. C. (2000). Como montar uma pequena fábrica de polpas de frutas (2. ed.). Viçosa: Centro de Produções Técnica.

Nogueira, D. H., Pereira, W. E., Silva, S. M., \& Araújo, R. C. (2007). Mudanças fisiológicas e químicas em bananas 'nanica' e 'pacovan' tratadas com carbureto de cálcio. Revista Brasileira de Fruticultura, 29(3), 460-464. http://dx.doi.org/10.1590/S0100-29452007000300011.

Oliveira, E. S., Barbosa, J. B., Talma, S. V., \& Pereira, S. M. F. (2012). Qualidade de polpas de frutas congeladas comercializadas em Campos de Goytacazes - RJ. Vértices, 14(1), 73-80.

Oliveira, M. E. B., Bastos, M. S. R., Feitosa, T., Branco, M. A. A. C., \& Silva, M. G. G. (1999). Avaliação de parâmetros de qualidade físico-químicos de polpas congeladas de acerola, cajá e caju. Food Science and Technology, 19(3), 326-332. http://dx.doi.org/10.1590/ S0101-20611999000300006.

Pereira, M. B. P. (2013). O papel dos antioxidantes no combate ao estresse oxidativo observado no exercício físico de musculação. Revista Brasileira de Nutrição Esportiva, 7(40), 233-245.

Pinheiro, M. A., Fernandes, G. A., Fai, C. E. A., Prado, M. G., Sousa, M. H. P., \& Maia, A. G. (2006). Avaliação química, físico-química e 
microbiológica de sucos de frutas integrais: abacaxi, caju e maracujá. Food Science and Technology, 26(1), 98-103. http://dx.doi.org/10.1590/ S0101-20612006000100017.

Raimundo, K., Magri, R. S., Simionato, E. M. R. S., \& Sampaio, A. C. (2009). Avaliação física e química da polpa de maracujá congelada comercializada na região de Bauru. Revista Brasileira de Fruticultura, 31(2), 539-543. http://dx.doi.org/10.1590/S0100-29452009000200031.

Rocha, W. S., Lopes, R. M., Silva, D. A., Vieira, R. F., Silva, J. P., \& Agostini-Costa, T. S. (2011). Compostos fenólicos totais e taninos condensados em frutas nativas do cerrado. Revista Brasileira de Fruticultura, 33(4), 1215-1221. http://dx.doi.org/10.1590/S010029452011000400021.

Rufino, M. S. M., Alves, R. E., Brito, E. S., Morais, S. M., Sampaio, C. G., Jimenez, J. P., \& Calixto, F. D. S. (2007). Determinação da atividade antioxidante total em frutas pela captura do radical livre DPPH (Comunicado Técnico, No. 127, pp. 1-4). Fortaleza: Embrapa.

Sancho, S. O., Maia, G. A., Figueiredo, R. W., Rodrigues, S., \& Sousa, P. H. M. (2007). Alterações químicas e físico-químicas no processamento de suco de caju (Anacardium occidentale L.). Food Science and Technology, 27(4), 878-882. http://dx.doi.org/10.1590/ S0101-20612007000400031.

Santos, C. A. A., Coelho, A. F. S., \& Carreiro, S. C. (2008). Avaliação microbiológica de polpas de frutas congeladas. Food Science and Technology, 28(4), 913-915. http://dx.doi.org/10.1590/S010120612008000400023.

Sebastiany, E., Moura, E. R., Rêgo, E. R., \& Vital, M. J. S. (2009). Perda de vitamina $C$ durante o armazenamento de Polpa de acerola congelada. B.CEPPA, 27(2), 281-288. http://dx.doi.org/10.5380/cep.v27i2.22039.

Shahidi, F., \& Naczk, M. (1995). Food phenolics: sources, chemistry, effects and applications. Lancaster: Technomic.

Silva, E. D. Fo., Araújo, G. S., Braz, A. S., \& Paz, J. G. H. (2013). Caracterização físico-química e física das polpas congeladas de caju (Anacardium occidentale $L$ ) comercializadas no município de
Campina Grande-PB. Divulgação Científica e Tecnológica do IFPB, 22, 35-39.

Silva, F. A. S., \& Azevedo, C. A. V. (2016). The Assistat Software Version 7.7 and its use in the analysis of experimental data. African Journal of Agricultural Research, 11(39), 3733-3740. http://dx.doi.org/10.5897/ AJAR2016.11522.

Silva, J. W. P., Silva, N. A., Borges, D. O., Santos, C. G. P., \& Rodrigues, L. M. (2011). Estudo de parâmetros físico-químicos de qualidade para polpas de acerola, abacaxi e maracujá. Fazu Revista, 8, 89-94.

Silva, L. M. R., Maia, G. A., Figueiredo, R. W., Sousa, P. H. M., Gonzaga, M. L. C., \& Figueiredo, E. A. T. (2012). Estudo do comportamento reológico de polpas de caju (Anacardium occidentale, L.), acerola (Malpighia emarginata, D.C.) e manga (Mangifera indica, L.). Semina: Ciências Agrárias, 33(1), 237-248. http://dx.doi.org/10.5433/16790359.2012v33n1p237.

Silva, N., Junqueira, V. C. A., Silveira, N. F. A., Taniwaki, M. H., Santos, R. F. S., \& Gomes, R. A. R. (2010a). Manual de métodos de análise microbiológica de alimentos e água (4. ed.). São Paulo: Livraria Varela.

Silva, V. K. L., Figueiredo, R. W., Brito, E. S., Maia, G. A., Sousa, P. H. M., \& Figueiredo, E. A. T. (2010b). Estabilidade da polpa do bacuri (Platonia insignis Mart.) congelada por 12 meses. Ciência e Agrotecnologia, 34(5), 1293-1300. http://dx.doi.org/10.1590/S141370542010000500030 .

Singleton, V. L., \& Rossi, J. A. (1965). Colorimetry of total phenolics with phosphomolybdic-phosphotungstic acid reagents. American Journal of Enology and Viticulture, 16(3), 144-158.

Sola, M. C., Oliveira, A. P., Feistel, J. C., \& Rezende, C. S. M. (2012). Manutenção de microrganismos: conservação e viabilidade. Enciclopédia Biosfera, 8(14), 1398-1418.

Stintzing, F. C., Stintzing, A. S., Carle, R., Frei, B., \& Wrolstad, R. E. (2002). Color and antioxidant properties of cyanidin-based anthocyanin pigments. Journal of Agricultural and Food Chemistry, 50(21), 6172-6181. http://dx.doi.org/10.1021/jf0204811. PMid:12358498. 